\title{
COLONIAL JUDGES, ADMINISTRATIVE OFFICERS AND THE BUSHE COMMISSION IN INTERWAR KENYA AND TANGANYIKA
}

\section{Paul Swanepoel*}

\section{ABSTRACT}

By focussing on a colonial commission of inquiry into the administration of justice in East Africa, this article outlines the major themes that dominated East Africa's legal "world" during the interwar period. The most important of these was the doctrine of indirect rule, which was the prevailing administrative policy during the period. Ultimately, there were two opposing views during this period. The traditional view, held by the judiciary, was that Africans must be "civilised" and integrated into a system of British courts. The opposing view, advocated by administrative officers, held that Africans must be protected against the harmful consequences of any contact with foreign law. One of the central tenets of the doctrine was placing customary courts under the supervision of administrative officers rather than under judges. Directly linked to the resulting legal problems were disagreements between the two sides as to the applicability of English law and customary law. More widely, this detailed study of the Bushe Commission provides an opportunity to view the administration of justice from the perspective of the Colonial Office as well as the colonial state.

Keywords: Colonial commissions of inquiry; East African legal history; indirect rule; administrative justice; colonial judiciary

* Lecturer, School of Law, Howard College, University of KwaZulu-Natal. 


\section{Introduction}

There have been multiple jurisdictional conflicts throughout the British Empire to the extent that they may be described as a structural feature of the colonial legal world. This article is focused on a particular legal conflict and how it changed the legal order in East Africa. Different kinds of colonial legal texts from various parts of the Empire - such as penal codes, colonial statutes and reported cases - interacted with each other, and this article examines a particular kind of legal text, namely the commission of inquiry. In this case it was known as the Bushe Commission, which conducted an investigation into the administration of justice in Kenya, Uganda and Tanganyika in 1933. Its remit was to investigate why the existing machinery of justice was not performing to the satisfaction of the East African governments and the Colonial Office. During the period when the commissioners were producing their report, however, the governors of the three East African territories wrote to the secretary of state for the colonies, requesting that most of the recommendations not be implemented. Their requests were duly granted, effectively rendering the Commission's report a nullity. Although in many respects the events surrounding the Commission involved a war of ideas rather than the realities on the ground, they are an excellent example of the attempts of the colonial state to manage conflicting interests, in this case those of the administration and the judiciary.

\section{Commissions of inquiry}

The commission of inquiry as a feature of colonialism has scarcely been dealt with by historians. Once a commission of inquiry had been appointed, whether in Britain or in the colonies, it was independent of all departments except for the fiscal control of the Treasury. Although service on commissions meant a significant sacrifice of time and energy, members of a commission were normally unpaid and were only given a small allowance for travelling expenses. There were seven categories of commission in respect of the following areas: public administration; social services; regulation of public morals; changes in private law; colonial administration; economic questions; and political questions. In Britain, public demand for commissions of inquiry was sometimes the result of prolonged public discussion of the subject. Through complaints made to the department in question, questions asked by members of parliament in Parliament, and letters written to the press, the demand for an investigation gradually grew. ${ }^{1}$

The varied problems of colonial administration resulted in the appointment of many commissions throughout the Empire, especially in India where commissions enjoyed a prestige that made them a popular form of investigation. Factors that gave rise to this included numerous instances of unrest, complaints by civil servants, 
members of parliament's questions in Westminster and requests by the viceroy. Other parts of the Empire (especially the West Indies) also welcomed the appointment of commissions. A commission could comprise a small body of supposedly impartial persons or experts, or a large body that was representative of all the main interests. Most commissions comprised between ten and twenty-three members. ${ }^{2}$

In the case of the Bushe Commission, it was characterised by its small size, comprising only six members. H Grattan Bushe was appointed as the chairman, and the remaining four members were ADA MacGregor, Kenya's attorney-general; CE Law, a judge from Uganda; Phillip Mitchell, Secretary for Native Affairs in Tanganyika; and W MacLennan Wilson, a prominent member of Kenya's settler community. The secretary of a commission played an important role and was normally a permanent official of the administrative class assigned by his department. The secretary for the Bushe Commission, JB Griffin, was the registrar of the High Court of Uganda.

The key to the success of a commission often depended on the character of the chairman. The aim was therefore to secure a distinguished civil servant who was willing to sacrifice his time and energy. ${ }^{3}$ Sir William Dale, legal assistant in the Colonial Office, described Bushe as being of "Irish extraction, a penetrating lawyer, he hit hard at humbug and could be sarcastic, not to say cynical. [He] fought to secure for the law and for the Colonial Legal Service its rightful place in the government of the empire". ${ }^{4} \mathrm{He}$ had a reputation for supporting the views of the colonial judiciary. This is borne out by the writings of Gilchrist Alexander, a judge who served in Tanganyika between 1920 and 1925. He wrote of his gratefulness that the legal department at the Colonial Office supported the judges against the "popular 'new despotism' favoured by most colonial governors" in his book, Tanganyika Memories: A Judge in the Red Kanzu. ${ }^{5}$ In particular, he praised Bushe for combating this trend. Although Alexander expressed this view eight years before the Bushe Commission began its investigations, his book was published in 1936, two years after the Commission had published its findings, and he emphasised his support for the Commission's recommendations.

The success of British commissions of inquiry was a consequence of the input of the ablest public administrators; the requirement of careful written statements as the basis for testimony; the willingness of men to serve as commissioners or witnesses; the use of experts; and an impartial view of the facts. ${ }^{6}$ Colonial Office officials who were ordinarily stationed in London were able to gain first-hand experience of the Empire by being part of commissions of inquiry. ${ }^{7}$ Within the limits of their prescribed functions, commissions had absolute powers to regulate their own proceedings and to

$2 \quad$ Idem at 92-94.

3 Gosnell 1934: 97.

$4 \quad$ Morris \& Read 1972: 113.

5 Alexander 1936: 18. 
admit or exclude persons from appearing before them. During preliminary meetings commissions had to interpret their terms of reference, and decide on holding open or private hearings. If the commission was investigating a matter of public interest, there was wide coverage in the press. ${ }^{8}$ The basis on which a commission based its findings was oral evidence given before it. The majority of commissioners were, however, not experienced in the challenging task of interviewing witnesses. In addition, their choice of witnesses was sometimes called into question, the lack of formality resulted in a wide range of possibilities of error and there were no methods of verifying the data. ${ }^{9}$

Sometimes, governors requested the Colonial Office for the appointment of a commission of inquiry. With reference to a possible commission of inquiry relating to the West Indies, reference is made to the "time-honoured device of a commission of inquiry to investigate policy options and thus obviate the requirement for immediate action". ${ }^{10}$ The West Indian labour disturbances between 1934 and 1939 led to a new approach to colonial development. Commissions of inquiry there established the causes of the protests and colonial governments successfully responded to the disturbances with coercion and concession. ${ }^{11}$

The Kenya Native Labour Commission that sat between 1911 and 1912 is an example of commissions of inquiry in East Africa. Evidence before this Commission made known that settlers believed violence to be integral to labour relations. ${ }^{12}$ Sometime after the Commission had presented its findings, members of the Kenya Native Punishment Commission noted the widespread use of violence by white landowners. ${ }^{13}$ In 1925 the Kenyan government appointed a Native Punishment Commission to inquire into the punishment of minors. Many of the offenders had been convicted in terms of legislation concerning legislation, hut and poll tax, pass laws, or for negligence and desertion. ${ }^{14}$

\section{The doctrine of indirect rule}

During the 1920s and 1930s there was growing dissatisfaction in administrative circles in Kenya and Tanganyika with the supervision of customary courts. They were technically under the control of the judiciary, even though in practice supervision was carried out by district officers. The administration also claimed that the High

\footnotetext{
Gosnell 1934: 118.

Kirk-Greene 2000: 44.

8 Gosnell 1934: 99-100.

9 Idem at $90-103$.

10 Thomas 2008: 9-11.

11 Johnson 2001: 319.

12 Shadle 2012: 66.

13 Idem at 67.

14 Clayton \& Savage 1974: 125.
} 
Court did not have knowledge of, or even an interest in, customary law. Accordingly, the administration wished to gain exclusive and direct control over customary courts in order to develop them according to the principles of indirect rule. The fact that administrative officers were laymen was considered to be an advantage, as they were able to determine cases without the intrusion of legal complexities. Lawyers, who were mostly trained in England, were barred from appearing in native courts. ${ }^{15}$

As far as was practicable, a district officer was on tour in each district at any particular time. During visits to county chiefs' headquarters, officers would inspect various records including native court records. Some matters were considered by administrative officers as appeals, and others were selected by them for reconsideration under their powers of revisional jurisdiction. The officer's supervisory powers included inspecting the court records in the presence of the court members, where complaints could be dealt with by revisional orders. Decisions were either made on the spot or matters were deferred for final consideration on return to headquarters. ${ }^{16}$

Administrative officers' notions of what constituted a fair trial were far removed from those of their judicial counterparts. In particular, judges expected presiding chiefs to maintain English procedural and evidentiary law. The judges' justification for this expectation was that this body of English common and statutory law had evolved with the purpose of protecting the rights of the accused person - without which it was impossible to conduct a fair trial as understood by lawyers. ${ }^{17}$ In sum, chiefs and the administrative officers who oversaw them offered simple and quick justice. The lawyers, however, believed in transplanting English criminal law and procedure. $^{18}$

During the first years under the British mandate, the government of Tanganyika was in a period of transition between the pioneering conditions of early conquest and the "public debate of post-war trusteeship ideology". ${ }^{19}$ In the 1920s, Sir Horace Byatt, the first governor, undertook a programme of reform designed to enlarge the role of chiefs within the provincial administrative system. This involved establishing native courts and promulgating native authority ordinances. ${ }^{20}$

Sir Donald Cameron was the first governor to fully endorse the new policy. The main controversy around the transformation arose as a result of Cameron's decision, adopted from Nigeria, to remove the High Court's power to review decisions from native courts, and to grant that right exclusively to provincial commissioners. Cameron feared that revisions by the High Court could "shake a native administration

16 Morris \& Read 1972: 20.

17 Ghai \& McAuslan 1970: 143.

18 Chanock 1985: 50.

19 Austen 1967: 583.

20 Idem at 582. 
to its very foundations". ${ }^{21}$ His fears were partly based on the Byatt period, when the Chief Justice, Sir William Morris Carter, had regularly interfered in native policy.

However, no such accusation could be made against his successor, Sir Alison Russell, who cooperated with the government in the implementation of indirect rule. Nevertheless, Russell believed that the High Court's revisional jurisdiction was an important part of the doctrine of indirect rule; when these powers were removed, he interpreted the government's action as an "unjustified return to a 'pioneer stage of administration"". ${ }^{22}$ His protests, and those of the unofficial members of the legislative council, merely delayed the implementation of Cameron's policy and he eventually resigned over the issue. ${ }^{23}$

Parallels may be drawn with other parts of the Empire during the interwar period. For instance, in Malaya there was often ill feeling between Malayan Civil Service officers and members of the Colonial Legal Service, especially at state and federal headquarters. One officer, who transferred from the Administrative Service to the Legal Service in 1938, observed that legal officers often resented the fact that

administrators were at the top of the heap, taking precedence over everyone regardless of professional qualifications. For his part the officer whose pet schemes had to vetted by a member of the bar would understandably bridle at legalisms that frustrated his plans. ${ }^{24}$

Indirect rule, first applied by Frederick Lugard in Uganda and Northern Nigeria, was not merely a practical means of administration, but also a wider, philosophical concept developed by his successors and admirers in other parts of Africa. ${ }^{25}$ Donald Cameron had previously served under Lugard in Nigeria and he defined the principle of indirect rule as

adapting for the purposes of local government the institutions which the native peoples have evolved for themselves, so that they may develop in a constitutional manner from their own past, guided and restrained by the traditions and sanctions which they have inherited (moulded or modified as they may be on the advice of the British Officers) and by the general advice and control of those officers. ${ }^{26}$

Cameron firmly believed he had successfully introduced a new system of administration into East Africa, although it is doubtful whether his policies were entirely new to the region. Lugard would certainly not have credited Cameron with having initiated the policy of indirect rule in the region, as he believed he had introduced it in Uganda many years before. ${ }^{27}$ With regard to legal matters, Cameron stated, in 1926, that

21 Idem at 589.

22 Ibid.

23 Ibid.

24 Heussler 1981: 295.

25 Iliffe 1979: 320.

26 Morris \& Read 1972: 3.

27 Ibid. 
[i]t is not the intention and is not the policy to impose upon the tribes a judicial system for them by ourselves and founded upon our idea of law and law courts, but to legalise and regulate the activities of whatever judicial machinery existed in the customs of the people. ${ }^{28}$

The doctrine of indirect rule consisted of four "pillars": native treasuries, native authorities, native courts, and supervision of native affairs by district officers. ${ }^{29}$ The reasons for installing traditional authority were set out in a circular issued by Cameron in 1925:

Everyone, whatever his opinion may be in regard to direct or indirect rule, will agree, I think, that it is our duty to do everything in our power to develop the native on lines which will not Westernize him and turn him into a bad imitation of a European - our whole education policy is directed to that end. We want to make a good African and we will not achieve this if we destroy all the institutions, all the traditions, all the habits of the people, super-imposing upon them what we consider to be better administrative methods, better principles; destroying everything that made our administration really in touch with the customs and thoughts of the people. We must not, in fact, destroy the African atmosphere, the African mind, the whole foundation of his race, and we shall certainly do this if we sweep away all his tribal organizations, and in doing so tear up all the roots that bind him to the people from whom he has sprung. ${ }^{30}$

\section{The administration}

The outlook of administrative officers serving during this period was moulded by their background and education, and it may be argued that they promoted the spirit and practice of indirect rule as much as their superiors. The structure of the administration allowed for the development of individualistic policy in the districts, with little interference from provincial commissioners or the secretariat. The outlook and methods of district administration were essentially paternalistic, and although it was widely accepted that Africans would assume responsibility for running their own territories, no officer expected to see this materialise in his own lifetime. ${ }^{31}$

Unlike administrative officers who served during the period prior to the First World War, officers in the 1920s and 1930s began to question the wisdom of colonial officials and missionaries imposing an alien civilisation on African peoples. They also began to take a keen interest in social anthropology and in studying indigenous African culture. ${ }^{32}$ Administrative officers tended to romanticise the tribal past and emphasised the virtues of traditional institutions such as native councils and courts.

28 Allott 1976: 368.

29 Pearce 1978: 10.

30 Buell 1928: 451-452.

31 Morris \& Read 1972: 11-13.

32 This was encouraged by the Colonial Service and anthropology was included in the courses of instruction given to administrative cadets before they left for East Africa. 
The prevailing sympathetic view of traditional African society was the foundation of the policy of indirect rule as understood in Tanganyika. Accordingly, indigenous institutions were seen as the only desirable organs though which the development of Africans might be advanced. Rather than the aspiring mission-educated urban African, the ideal became the traditional chief or elder whose authority was rooted in indigenous institutions and who administered justice according to customary law. ${ }^{33}$

Essentially, administrative officers sought to protect Africans from professional lawyers, who were mostly resident magistrates and judges, and they were able to do this more effectively than were the missionaries. They saw lawyers as being overly legalistic and as having the blind belief that English law and practice were as appropriate in all its detail in an African society, as they were in England. ${ }^{34}$

\section{The background to the Commission}

By the early 1930s, public attention was drawn to the issue of the administration of justice in East Africa. This was after several cases had led to uneasiness in the Colonial Office as to the methods of criminal procedure that had been adopted. Chief among these was the Bagishu trial in Kenya, in which four men were convicted of murder and sentenced to death. ${ }^{35}$

The facts of the case were that the body of an African man was found on the farm of a certain Oswald Bentley, near Kitale in Kenya's Western Province. As a result of statements made to a European police officer, Assistant Inspector Joseph Dale, by two African constables who had been left on the farm, two employees of Bentley were arrested. A further two men were subsequently arrested and all four were charged with the murder. Under Kenyan colonial law in force at the time, police officers without a warrant from a resident magistrate were not permitted to keep suspects in custody for longer than twenty-four hours, exclusive of the time necessary for the journey to the resident magistrate's court. The farm was only seven miles from the court, and yet the men were detained for longer than twenty-four hours. This was but the first in a long series of abuses and blunders by the police. Other Africans on the farm, including a woman and child, were taken into custody and were subjected to intimidation and ill-treatment by African constables under the supervision of Dale. A man employed as a tractor driver by Bentley, one Busiko, was intimidated by the police into making a statement, which afterwards formed the principal basis of the charge framed against the four accused persons. ${ }^{36}$

The case was tried by the Supreme Court of Kenya at Kitale before Judge John Stephens, and Busiko was selected as the main witness for the prosecution. Stephens

35 Bagishu Murder Trial: Report of the Commission of Inquiry (Nairobi, 1931). The Bagishu are an ethnic group who inhabit the district of Kitale in the Western Province of Kenya.

36
Stibbs 1978: iv.

Morris \& Read 1972: 16.

ethnic gro 
convicted the four accused men of murder and sentenced them to death. ${ }^{37} \mathrm{~A}$ key piece of the evidence was that the accused persons had killed and eaten a chicken after the alleged murder, which the court accepted as a local custom. Although no evidence was led on this point, the administration used this as an example of the judiciary's incompetence..$^{38}$ The convicted men were granted leave to appeal within a month, and, as a result of Bentley's efforts, it was discovered that the conviction was based on statements to the police that had been obtained under duress.

A commission of inquiry chaired by the chief native commissioner, GV Maxwell, was set up to investigate the circumstances leading up to the trial. This led to the Colonial Office setting up a further commission under the direction of Bushe to investigate the administration of criminal justice in East Africa. ${ }^{39}$

\section{The Bushe Commission}

The remit of the newly-appointed commissioners was to investigate why the existing machinery of justice was not performing to the satisfaction of both the East African governments and the Colonial Office. During the course of their investigations, which occurred between late March and early May 1933, the commissioners travelled 2,200 miles, visiting nine places. Eighty-five witnesses testified, including four judges, two resident magistrates, three registrars, and six legal officers..$^{40}$ The Commission's report, published in 1934, stated that the legal system in East Africa was unworkable and recommended major changes. These included reducing the judicial powers of administrative officers and transferring all serious criminal cases to the High Court. Accordingly, it suggested increasing the number of judges. During the period when the commissioners were producing their report, however, the governors of the three East African territories wrote to the secretary of state for the Colonies, requesting that most of the recommendations be not implemented. Their requests were duly granted effectively rendering the Commission's report a nullity. ${ }^{41}$ The Colonial Office agreed with the governors' view that administrative officers should not be stripped of their magisterial functions. Apart from the reality that financial constraints required minimal administrative expenditure, it was officially recognised that administrative officers had experience that was essential in determining such questions as motive, extenuation and the credibility of evidence in the native courts. As a consequence it was acknowledged that until the post-war period, the cheapest and most effective

37 Idem at 7.

38 Read 1999: 112.

39 Morris \& Read 1972: 88-96.

40 Report of the Commission of Inquiry into the Administration of Justice in Kenya, Uganda and the Tanganyika Territory in Criminal Matters, Command Paper 4623 (London, 1934) Appendices I and II.

41 Morris \& Read 1972: 318 
method of administering justice in rural districts would continue to be through the non-professional magistrate. ${ }^{42}$

\section{$7 \quad$ Recommendations}

The Commission made forty-seven main recommendations that are listed at the end of its report, a small selection of which are discussed below. These do not include numerous small points of detail referred to in the text. In their report to the Colonial Office after the investigation had been completed, the commissioners expressed their dissatisfaction with the existing framework for the administration of justice:

It is no exaggeration to say that the machinery for the administration of justice, as apparently set up by law in these territories, does not work and as at present constituted cannot work. This is a grave statement but is fully supported by the evidence which we have heard. No machinery, however perfect it may be in itself, can perform its primary function of meting out justice to the people unless it takes justice to the people and administers it with despatch, with independence, with certainty and with skill. ${ }^{43}$

They identified a number of problematic areas, recognising that although there were different conditions in each territory, the main problems were common to all of them.

\section{Extended jurisdiction}

In areas that were not covered by high courts, extended jurisdiction was sometimes conferred on magistrates. The Commission resolved that this practice should, where possible, cease. Extended jurisdiction generally occurred in outlying districts in Kenya and Uganda that were not served by a high court, granting magistrates the power to try any criminal case. In Uganda, extended jurisdiction had been implemented in thirteen of the eighteen districts. The Commission recommended that extended jurisdiction should apply only in the two most isolated districts. The situation was different in Tanganyika as magistrates' sentencing powers were in general restricted to a period of two years. ${ }^{44}$

\section{Court procedure}

Apart from the issue of extended jurisdiction, other matters were raised by the administration, such as the argument that English criminal procedure was beyond the comprehension of accused persons, who were normally uneducated and unrepresented by counsel, and could not speak English. Practical matters were set out in the report

42 Report of the Commission of Inquiry at para 156.

43 Idem at para 18.

44 Morris \& Read 1972: 99. 
such as that measures should be adopted to provide a reliable body of interpreters. ${ }^{45}$ Similarly, district officers were instructed to keep a list of suitable assessors. ${ }^{46}$ As in Kenya, stenographers were to be appointed in the other two territories. ${ }^{47}$

\section{Revision and confirmation by the High Courts}

Until the mid-1930s high courts in the three territories had full powers of revision, confirmation and appeal over resident magistrates' courts, district courts and native courts. Courts were able to revise the convictions or sentences of requested cases. In addition, the convictions and sentences of certain classes of matters were required to be sent to a High Court judge. During this period, most customary-law cases reached the superior courts only on appeal from native courts and only a handful were heard by the high courts sitting as courts of first instance. This was in stark contrast with the situation in West Africa where family and land matters were frequently heard by the high courts. This was arguably because the region had been under colonial administration for a much longer period; in addition, there were substantially more African lawyers there than in East Africa. ${ }^{48}$ During the interwar period in East Africa, the right of the High Court to alter sentences passed by administrative officers was disputed. To the relief of the judges, the Commission recommended that confirmation and revision would continue. ${ }^{49}$

\section{4 "Reconciliation"}

Following a tradition of borrowing provisions from elsewhere in the Empire, the Commission recommended that the East African governments adopt a provision from the Nigerian Supreme Court Ordinance regarding "reconciliation". ${ }^{0}$ This Ordinance allowed courts to facilitate settlement in an amicable fashion regarding proceedings for common assault or offences not amounting to a felony by means of payment of compensation or other terms approved by the Court. ${ }^{51}$

\section{The judicial perspective}

As far as the judges were concerned, the only change necessary was to increase the size of the judiciary. Sir Robert Hamilton expressed this point of view as follows:

45 Report of the Commission of Inquiry at para 131.

46 Ibid.

47 Ibid.

48 Morris \& Read 1972: 174.

49 Report of the Commission of Inquiry at para 157.

50 Idem at para 184.

51 Ibid. 
Though the limits of a District Officer's jurisdiction are still in question, where a sufficient number of judges is not available and extended jurisdiction has consequently to be conferred upon lay magistrates, the state of affairs might not be inaptly described as one of "necessity having no law"; but is it in fact one of necessity if the difficulty can be largely overcome by the extension of the judicial staff? This is the line taken by the Report, in the course of which the old controversy as between the District Officer with knowledge of the Natives and the judge with knowledge of the law is carefully analysed. ${ }^{52}$

As a consequence, Kenya was assigned an extra judge, and two extra judges were appointed in Tanganyika. This then led to a debate about the decentralisation of the judiciary in Tanganyika. The Commission recommended that one of the two new judges should be posted to Tanga and the Northern Province. However, in the opinion of the Chief Justice, Sir Joseph Sheridan, it was best if both judges were stationed in Dar-es-Salaam. He did not believe in decentralisation unless there were good reasons for it:

It is recognised that a High Court with some of its members stationed away from headquarters is not as strong as when all the Judges reside at headquarters, and if the circuits can be held as expeditiously and effectually by sending out Judges from Dar es Salaam, as I am satisfied they can, in the case of Tanga and Northern Province, there is no need for any decentralisation in so far as that part of the Territory is concerned. ${ }^{53}$

Sheridan could not accept there was sufficient work for a resident judge in the region, adding that stationing a judge in the Northern Province would necessitate the building of an expensive library. By keeping the judges at Dar-es-Salaam, there would be no extra expense for subordinate staff, in particular a crown counsel in Tanga. Nevertheless, he conceded that the town of Mwanza, on Lake Victoria, required a permanent judge, given its long distance from the coast. He also favoured the extension of jurisdiction of resident magistrates to "relieve district officers from their magisterial duties for their administrative duties". ${ }^{54}$ Sheridan's concerns echoed similar fears in other branches of the Colonial Service. For example, a report for the Committee for Colonial Agricultural, Animal Health, and Forestry Research in 1948 concluded that the isolation in which many officers served was a "serious bar to efficiency": 55 the report recommended a policy of grouping officers together, instead of scattering them at many territorial stations. ${ }^{56}$

52 Hamilton 1935: 10.

53 Tanzania National Archives (TNA) DSA 21429/II, Sir Joseph Sheridan's response to the Commission's Report, 1 Sep 1933.

54 TNA DSA 21429/II, Sir Joseph Sheridan's response to the Commission's Report, 1 Sep 1933.

55 "Report by Committee for Colonial Agricultural, Animal Health, and Forestry Research" Recommendations for the Organization of Colonial Research in Agriculture, Animal Health and Forestry Col No 219 (London, 1948) at 7.

Ibid. 
Sheridan also believed that new judges should be paid the same as existing ones, and under no circumstances should a judge be paid less than a provincial commissioner, the highest rank of administrative officer. His Kenyan counterpart, Sir Jacob Barth, also supported these views. ${ }^{57}$ Judges were second in rank to the governor in both Kenya and Tanganyika, and the chief justice was normally the second highest paid officer. Sheridan was anxious to preserve the judiciary's place in this hierarchy commenting that " $[\mathrm{h}]$ owever erroneous it may be there is no doubt that the public judges the prestige of an office by the emoluments paid to the holder". ${ }^{58}$ Echoing concerns by recruitment officials in the Colonial Office, he also feared that a salary less than that of the present judges would not attract the best recruits. ${ }^{59}$

In connection with the exercise of the judiciary's revisionary powers, Haythorne Reed, Tanganyika's acting chief justice in the late 1920s, complained to the governor that there were a number of cases where administrative officers had broken procedural rules. He tried to uphold them wherever he could, but commented that such judgments would have been rejected in jurisdictions such as India, Zanzibar, England and South Africa. ${ }^{60}$ The procedural errors he referred to included administrative officers submitting as court evidence long reports written by themselves to their superior officers on the facts of a case; accused being charged with previous convictions before the end of a case; accused being cross-examined by the court instead of merely being examined; and administrative officers incorrectly grouping charges together. ${ }^{62}$ Reed stressed that "[e]veryone concerned with the administration of justice knows that when form goes, justice goes with it, and decisions are given in accordance with what the court thinks the law ought to be, instead of in concordance with what it knows the law to be". ${ }^{62}$ The derisory response of Sir Phillip Mitchell, the Native Commissioner, was couched in the following terms:

Livingstone under his mango tree probably got a great deal nearer to the truth, and to justice, than a judge on a bench; and I wish Your Excellency could see some of the 'well kept records' to which His Honour refers! But in view of an already existing divergence of opinion on the subject of Native Courts it will I think be wise not to antagonise His Honour in a matter which is peculiarly his province: though why having swallowed 'Native law' (undefined of course) he should baulk at 'Native Procedure' is beyond my comprehension. ${ }^{63}$

57 Report of the Commission of Inquiry at para 110.

58 TNA DSA 21429/II, Sir Joseph Sheridan's response to the Commission's Report, 1 Sep 1933.

59 Ibid.

60 TNA AB 305, Haythorne Reed, Acting Chief Justice, Tanganyika to Governor, Tanganyika, 3 May 1926.

61 Ibid.

62 Ibid.

63 TNA AB 305, Phillip Mitchell, Commissioner for Native Affairs, Tanganyika to Governor, Tanganyika, 9 Apr 1926. 
Mitchell believed Africans' perceptions of judges were based on their knowledge of local conditions:

The Native idea is of a kindly judge, with complete and often privately acquired knowledge of local personnel and circumstances, asking and being given corroborating information in the vernacular, and delivering judgment coram populo [in the presence of the people]; execution following immediately. ${ }^{64}$

Twelve years after the Bushe Report was published, Mark Wilson, who served as a judge in Tanganyika between 1936 and 1948, compiled a report in 1945 on the administration of justice in that country. ${ }^{65}$ This stated that the size of the judiciary had increased from two to five during the interwar period. The circuit system had also expanded, and by the end of the Second World War, the entire territory, apart from the Southern Province, was covered. The increased size of the judiciary was accompanied by an increased professional magistracy. ${ }^{66}$ In 1945 , when the policy of indirect rule was beginning to be seen as outdated, he wrote of the lack of nexus between the two court systems. He reiterated the standard judicial view that the High Court should have remained the final court of appeal from the African courts. This was a reference to Donald Cameron's success in removing, in the face of fierce resistance by the judges, the right of the High Court to hear appeals from customary courts. ${ }^{67}$

\section{The administration's perspective}

The following paragraphs detail the views of four administrative officers in Tanganyika. These views were expressed to their respective provincial commissioners, who then passed them on to members of the Commission. This was seen as an opportunity to air their grievances about the administration of justice in their areas. To add weight to their views, administrative officers often gathered "evidence" from Africans in their districts, to support their position. For most, the overriding concern was that the powers of the High Court of Tanganyika to supervise African courts should be removed. ${ }^{68}$ The High Court came under more adverse criticism than any other judicial institution, and judges were widely criticised for passing sentences on accused persons in the rural areas, from their headquarters in Dar-es-Salaam. As a result, sentences were often not handed down for long periods of time, and, as a result, they lost much of their deterrent value. One person who had been persuaded

64 TNA DSA 21429/I, Phillip Mitchell, Minute, 17 Mar 1932.

65 TNA DSA 33058, Proposals for Post-War Developments and Improvements in the Administration of Justice in the Tanganyika Territory, 26 May 1945.

66 TNA DSA 33058, Mark Wilson, Internal Memorandum, 25 May 1945.

67 Ibid.

68 TNA DSA 26002, District Officer, Shinyanga, to Provincial Commissioner, Tabora, 12 Feb 1932. 
by the district officer at Shinyanga to provide "evidence" stated that Africans often asked how the "Big Judges" could understand and weigh cases when they heard them so far away and knew nothing of the tribe or the district. ${ }^{69}$

One district officer compared the system of professional magistrates and judges in Tanganyika to the system that would have resulted had the Allies lost the First World War. Englishmen would have had to stand trial in London before German judges: the proceedings would have been in German, the judges would have had no knowledge of English law and customs, and the accused would have had no knowledge of German:

I consider that the present system of "professional" magistrates and judges should be abandoned. The conception that because a man has passed Bar examinations and has eaten a number of dinners in one of the Inns of Court he is fit to be a Magistrate is, in my opinion, fallacious. It is a relic of the old English guild system, the modern development of which in more humble occupations is the trade union. Much more than the elemental knowledge of English law required by Bar examinations is necessary to fit a man to administer justice in native territories. A knowledge of the languages, habits, customs, and psychology of the people is necessary and this can never be acquired by sitting in Court. A knowledge of the laws which he is called upon to administer should certainly be possessed by every Government officer and Administrative Officers, whose whole functions are based on the laws, probably possess a more comprehensive familiarity with them than any other official. ${ }^{70}$

Severe delays between arrest and trial were one of the major issues that came before the Commission. ${ }^{71}$ For instance, the district officer in Singida, Tanganyika, reported a delay of nine months and there were an average of seven months in several other cases. ${ }^{72}$ In describing a typical witness, one judge commented that

[t]heir vague ideas as to time, their habit of mixing up what they have been told with what they have themselves, seen or heard, their vivid imaginations, and their loose manner of thought and speech all combine to mislead and mystify anyone trying to find out what really did happen. ${ }^{73}$

He also advised that evidence should only be taken once. Under the system at the time, however, an accused person was required to give evidence before a magistrate in a preliminary hearing, and then again in the High Court. ${ }^{74}$ Another officer wrote of an instance when a person was found dead on the side of a main road. No one reported it, fearing that they would have to appear as witnesses in the High Court in Tabora, Tanganyika - thus being forced to spend weeks away from their lands. There

69 Ibid.

70 TNA DSA 26002, WH Scupham, District Officer, Mwanza, to Provincial Commissioner, Mwanza, 29 Feb 1932.

71 TNA DSA 26006, District Officer, Singida, 12 Mar 1932.

72 Ibid.

73 Ibid.

74 Ibid. 
were even cases where people had attempted to conceal crimes in order to avoid the risk of being called as witnesses. ${ }^{75}$

An account by one of the district officers of a murder case illustrates the many disadvantages of the legal system in the early 1930s. The case was first heard in Lindi, Tanganyika, by a provincial commissioner, under extended jurisdiction. ${ }^{76}$ The crime had taken place over 100 miles away, and the witnesses - some of them so old that they had to be carried - were brought in at the height of the rainy season. The two accused persons were found guilty and the Commissioner's finding was confirmed by the High Court. On appeal, it was discovered that a certain defence witness had not been called, and a retrial was ordered. At the retrial in Masasi, Tanganyika, about twenty witnesses testified - including the witness who was not present at the original trial - and the Court came to the same conclusion and convicted the accused. During the period between the first and second trials, however, the High Court held that the case should have been tried under the new Criminal Procedure Code of 1930, instead of under the Indian Penal Code of $1860 .{ }^{77}$ The High Court then heard the case at Lindi almost a year after the first hearing, and acquitted the two accused persons. The judge admitted that some of the witnesses told him a completely different story to that they had told to the provincial commissioner, and that there were serious discrepancies. Not surprisingly, the local population was astounded at the result. ${ }^{78}$ The case illustrates the farcical nature of many court cases in colonial Tanganyika. The material cost of testifying was usually enormous, as witnesses would be forced to leave their lands and wait for weeks or even months at the courthouse while the wheels of justice gradually turned. Witnesses therefore developed evasive methods, such as avoiding crime scenes or disappearing into the bush for the duration of the trial. $^{79}$

\section{Confessions}

The most contentious legal issue concerned the law relating to confessions. The Commission recommended altering the law relating to confessions in Kenya and Tanganyika to that prevailing in Uganda. Among other things, this meant that

75 TNA DSA 26002, District Officer, Shinyanga, to Provincial Commissioner, Tabora, 12 Feb 1932.

76 Extended jurisdiction was governed by the Extended Jurisdiction Order of 1930. The High Court was able to direct that each case was to be heard by an "efficient" officer. Not every officer was deemed fit to exercise extended jurisdiction, and judges were able to decide this from records kept in the High Court. TNA DSA 21429/II, Sir Joseph Sheridan's response to the Commission's Report, 1 Sep 1933.

77 Regarding Indian laws, these were introduced to East Africa as a result of close ties between Zanzibar and British-ruled India. As a result, English law was supplemented by Indian codes that mainly governed aspects of criminal law and procedure. See Ghai \& McAuslan 1970: 4-6.

78 TNA DSA 26006, District Officer, Memorandum, Singida, 12 Mar 1932.

79 Ibid. 
confessions made to police officers would be admissible in court, whereas the law in Kenya and Tanganyika stipulated that only confessions made to resident magistrates would be admissible. This was to increase the likelihood that such confessions would not be made under duress. Sheridan's view was that the law of evidence on the subject of confessions made to police officers should not be altered, and this represented the views of the majority of judges in the region. ${ }^{80}$

The only judge on the Commission, CE Law from Uganda, requested that the section of the Indian Evidence Act of 1872 excluding confessions made to police officers should be retained. ${ }^{81}$ Later, a judge from Kenya, John Lucie-Smith, stated that "persuasion" in various forms was frequently applied before a suspect was asked to give a confession. ${ }^{82}$ Similarly, in Surumbu s/o Singana \& Three Others, the appellants were convicted of murder in the High Court of Tanganyika. ${ }^{83}$ On appeal, Sheridan CJ concluded that the evidence on which the first two appellants were convicted could not stand ${ }^{84}$ In addition there was evidence that the other two appellants had made their confessions to the local district officer. The defence submitted that this evidence was inadmissible on the grounds that the district officer was deemed to be a police officer under the statutory law then in force. ${ }^{85}$ The relevant section of the Indian Evidence Act rendered inadmissible any confession made to a police officer. A series of Court of Appeal decisions had established that the words "police officer" included district officers who were in charge of the police in their districts, provided they were acting in that capacity at the time the statement was taken. In Surumbu, the district officer was on tour when he met the two appellants who were under arrest. He then ordered a policeman to bring them to him individually and asked each of the appellants in turn if they wished to say anything, or give him any general information, or if they wanted to tell him about the murder and what had happened. He told the appellants that "I am investigating the matter. I have nothing to do with it. When I have finished I will send it to the bwana Judge" ${ }^{86}$ The Court of Appeal ruled that it was not part of the duties of a magistrate to call suspects before him with the purpose of questioning them about their movements, and that the district officer was in fact acting as an investigating officer on this occasion. The Court established the principle that district officers needed to carefully distinguish their functions, and make it plain when recording the confessions of suspects in police custody that they

80 Sir Jacob Barth, Sidney Abrahams, John McDougall and Horace Hearne agreed with Sheridan on this point.

81 Kenya National Archives (KNA) AP/1/1660, Sir Joseph Sheridan to Acting Governor, Kenya, 11 Jun 1935.

82 KNA AP/1/1660, Sir John Lucie-Smith, Internal Correspondence, 9 Apr 1943.

831940 (7) East African Court of Appeal (EACA) 55. S/o denotes "son of".

84 Webb \& Francis (Uganda) concurred.

85 Section 25 of the Indian Evidence Act and s 7 (3) of the Tanganyika Police Ordinance of 1937, cited in 1940 (7) EACA 55 at 56. The legislation was cited in the judgment.

86 1940 (7) EACA 55 at 56. 
were not themselves taking part in the investigation, and were acting as magistrates. The appeal was accordingly allowed. ${ }^{87}$

In the experience of Mark Wilson, a judge in Tanganyika, it was only in a tiny minority of cases that any accused person volunteered to make a confession without some form of prompting or persuasion by those holding him in custody. He disagreed with the idea that there was a widespread desire to confess. ${ }^{88}$ There was also disagreement within the judiciary on the issue, with some willing to allow confessions to police. ${ }^{89}$ Another complication arose from the fact that there were over a hundred dialects in Tanganyika, and in most cases confessions to European officers had their origins in a statement to an African police officer or interpreter acting as a medium. ${ }^{90}$

Rather than making broad policy statements when responding to the Report, judges preferred to focus on specific points. For instance, Sir Alison Russell raised the question of guilty pleas. ${ }^{91}$ Often, owing to the problems of interpreting from Swahili into English, interpreters would ask accused persons leading questions such as "do you admit doing this?" or "is it true that you struck him"? Accused persons would often answer "nilikosa", which can be translated as "I have done wrong". Such guilty pleas would not have been accepted in England, as it would not have been clear to the Court whether the accused person had admitted to committing every element of the offence. For example, on a charge of murder, it must have been be clear to an English Court that the accused person had the requisite capacity to commit the offence, that he intended to execute it, and that he had no lawful excuse. Russell referred to his Handbook for Magistrates, ${ }^{92}$ which recommended that magistrates should not accept as a plea of guilty anything that fell short of a full acknowledgement of responsibility for all the elements of an offence. In addition, the statement of the accused person was to be in his own words rather than a simple "yes" or "no". 93

The issue of confirmation and revision was central to the debate, and the Commission recommended that all sentences of over six months' imprisonment, whippings of over twelve strokes, and fines over $£ 50$ would be subject to revision and confirmation by the High Court. ${ }^{44}$ Administrative officers in Kenya felt these restrictions served no useful purpose and were a cause of embarrassment to the lower courts. This was mainly because judges frequently overturned verdicts and sentences

Ibid.

88 Kenya National Archives (KNA) AP/1/1660, Mark Wilson, Internal Correspondence, Apr 1943.

89 KNA AP/1/1660, Lancelot Lloyd-Blood, Internal Correspondence, Apr 1943.

90 TNA DSA 21429/II, Joseph Sheridan's Response to the Commission's Report, 1 Sep 1933.

91 Report of the Commission of Inquiry at para 104.

92 Cited in para 104 of the Report.

93 Ibid.

94 Idem at para 154. 
passed by district commissioners. ${ }^{95}$ Characteristically, Sir Jacob Barth, one of Kenya's chief justices, believed that many district courts were staffed by unqualified people. This was because the administration tended to appoint officers as secondclass magistrates shortly after they had passed the basic Kenyan law examination. In his view, it was essential that officers were supervised by a higher authority. ${ }^{96}$ Significantly, his opinion was supported by some Africans who testified before the Commission that the Supreme Court's intervention was helpful in pointing out mistakes and giving guidance to district commissioners. ${ }^{97}$

Later in the Report, Barth referred to a confirmation case in Kenya, where Judge Samuel Thomas had criticised administrative officers' insensitivity to the rights of Africans. ${ }^{98}$ Thomas made reference to the appendix of the first volume of the Kenya Law Reports ${ }^{99}$ which stated that justice in Kenya should not be administered in the "rough and ready style of which some affect to think highly, but which is generally the sign of lack of experience or of sympathy and patience and not infrequently results in what is in reality rough and ready injustice". ${ }^{100}$ He claimed that administrative officers often used this style to excuse errors in the proper conduct of trials.

\section{Wider recommendations}

Although the commissioners acknowledged that the bulk of magisterial work would have to be performed by administrative officers for a considerable period of time to come, they recommended that judicial work should gradually be taken over by professional magistrates from the Legal Service. ${ }^{101}$ The Commission rejected the suggestion that administrative officers be given enhanced powers, and recommended that additional judges be appointed. ${ }^{102}$ More specifically it acknowledged that judges were often at a disadvantage compared to administrative officers, as they knew little about the district where the crime was committed, and often did not have the opportunity to hear witnesses. Their powers of confirmation and revision, however, were judged by the commissioners to be justified, given the wide jurisdiction and sentencing powers granted to district commissioners. ${ }^{103}$

Although a number of the Commission's recommendations were accepted by the East African governments, its broader findings were unfavourably received. The governors refused to accept that the administration of justice by administrative officers

95 Ibid.

96 Ibid.

97 Ibid.

98 Idem at para 156.

99 I have, unfortunately, not had access to this volume.

100 Ibid.

101 Idem at para 66.

102 Idem at paras 55, 60-61, 63.

103 (TNA) DSA 21429/III, Secretary of State, to Governor, Kenya, 12 Nov 1924. 
was in principle undesirable, that their powers should be reduced, and that they would eventually be superseded by professional magistrates. The recommendations that the governors disagreed with were referred to the East Africa Governors' Conference of 1934, following which the Secretary of State for the Colonies, Sir Phillip CunliffeLister, decided in favour of the governors. ${ }^{104}$

Although the wider recommendations of the Report were successfully opposed by the governors, the inquiry marks a watershed in East Africa's legal history. The administration's success was a limited one and they failed to reform the judiciary in the years leading up to 1939. After the Second World War, administrative officers accepted that the doctrine of indirect rule was unsuitable and were increasingly content to leave judicial work to professional magistrates. Once administrative officers had accepted the progressive elimination of their magisterial powers, the controversies between the judiciary and the administration receded. Moreover, as the prospect of independence became clear, many administrative officers worried that the British institutions would be rapidly dismantled. Accordingly, they strongly supported the judiciary in maintaining the English legal system in its purest form: as the strongest safeguard against the supposed autocratic tendencies of the leaders of the liberation or the eroding of individual rights. After the war, English law and procedure were applied with increased rigidity, Indian statutory law continued to be replaced, and increased attention was given to English precedent. ${ }^{105}$

\section{Conclusion}

A study of the Bushe Commission provides an opportunity to view the administration of justice from the perspective of the Colonial Office as well as the colonial state. The differences of opinion over the essential requirements of justice were largely confined to areas of the legal system where the judicial and administrative circles came into direct conflict in areas such as control of customary courts, the determination of officers' judicial powers, and the level of adherence to court procedure. Ultimately, there were two opposed views during this period. One was that Africans must be "civilised" and integrated into a system of "British courts", while the other held the view that Africans must be protected from the harmful consequences of contact with foreign law. The history of the courts and the law during the interwar period is the history of the struggle between these two ideas. ${ }^{106}$ The events of this period reveal the relatively weak and vulnerable position of the judiciary within the colonial state

104 The governors in question were Sir Joseph Byrne (Kenya), Sir H MacMichael (Tanganyika), and Sir BH Bourdillon (Uganda). Colonial Office List (London, 1934).

105 Morris \& Read 1972: 102-108. See, also, n 77.

106 Allott (1976): 368. 
and, at the same time, the critical role of the judges with regard to the day-to-day administration of justice.

The appointment of a commission was an attempt to resolve a legal conflict in a colonial territory from "outside". Its findings exposed divisions both within the Colonial Office and the colonial state. In some respects, however, the judiciary was able to claim victory. Additional judges were appointed, which enabled the judiciary to increase the number of circuits and to reach more remote areas than had previously been possible. The high courts in the three territories also retained their powers of revision, confirmation and appeal in respect of the resident magistrates' courts, and after the Second World War the animosity between the two branches largely disappeared as the administration became increasingly willing to leave judicial matters to professional magistrates.

\section{BIBLIOGRAPHY}

Alexander, Gilchrist (1936) Tanganyika Memories: A Judge in the Red Kanzu (London \& Glasgow)

Allott, AN (1976) "The development of the East African legal system during the colonial period" in Low, DA \& Smith, Alison (eds) History of East Africa Vol III (Oxford): 348-382

Austen, Ralph A (1967) “The official mind of imperial rule: British policy in Tanganyika, 19161939" in Gifford, Prosser \& Louis, Wm Roger (eds) Britain and Germany in Africa: Imperial Rivalry and Colonial Rule (New Haven \& London): 577-606

Buell, RL (1928) The Native Problem in Africa Vol I (New York)

Chanock, Martin (1985) Law, Custom and Social Order: The Colonial Experience in Malawi and Zambia (Cambridge)

Clayton, Anthony \& Savage, Donald C (1974) Government and Labour in Kenya, 1895-1963 (London)

Ghai, Yash P \& McAuslan, JPWB (1970) Public Law and Political Change in Kenya: A Study of the Legal Framework of Government from Colonial Times to the Present (Nairobi \& New York)

Gosnell, HF (1934) "British royal commissions of inquiry” Political Science Quarterly: 84-91

Hamilton, Robert (1935) "Criminal justice in East Africa: Report on the administration of justice in Kenya, Uganda and Tanganyika" $J$ of the Royal African Society 34: 7-26

Heussler, Robert (1981) British Rule in Malaya: The Malayan Civil Service and its Predecessors, 1867-1942 (Oxford)

Iliffe, John (1979) A Modern History of Tanganyika (Cambridge)

Johnson, Howard (2001) "The British Caribbean from demobilisation to constitutional decolonization" in Brown, Judith \& Louis, W Roger (eds) The Oxford History of the British Empire: Volume IV The Twentieth Century (Oxford): 597-623

Kirk-Greene, Anthony H (2000) Britain's Imperial Administrators, 1858-1966 (London)

Morris, HF \& Read, James S (1972) Indirect Rule and the Search for Justice: Essays in East African Legal History (Oxford) 


\section{PAUL SWANEPOEL}

Pearce, RD (1978) The Evolution of British Colonial Policy towards Tropical Africa, 1938-1948 (DPhil, University of Oxford)

Read, James S (1999) "Indirect rule and the search for justice" in Smith, J (ed) Administering Empire: The British Colonial Service in Retrospect (London)

Shadle, Brett (2012) "Settlers, Africans, and inter-personal violence in Kenya, ca 1900-1920s" International J of African Historical Studies 45: 57-80

Stibbs, TPC (1978) Aspects of the Colonial Office Administration of the Trusteeship Concept, with Special Reference to Kenya and Nigeria, 1919-1943 (DPhil, University of Oxford)

Thomas, Martin (2008) "The political economy of colonial violence in interwar Jamaica", unpublished paper for conference entitled "Terror and the Making of Modern Europe" (Stanford University, CA). 